agreement with what has been stated above, an expansion of three or four times usually sufficed to convert the ordinary water surface into one upon which superficial viscosity was tending to disappear.

I propose to make determinations of the actual tension of surfaces contaminated to various degrees; but in the meantime it is evident that the higher degrees of purity do not imply much change of tension. In the last experiment, upon a tolerably pure surface, if we cause the needle to oscillate rapidly backwards and forwards through a somewhat large angle, we can clear away the contamination from a certain area. This contamination will, of course, tend to return, but observation of motes shows that the process is a rather slow one.

The smallness of the forces at work must be the explanation of the failure to clean the surface in Plateau's apparatus by mere expansion. For this experiment the end wall was removed from the tail-piece (Fig. 3), and a large fiexible hoop substituted. By this means, it was hoped that when the whole was placed in the bath it would be possible, by mere expansion of the hoop, to obtain a clean surface in the well. The event proved, how ever, that the purification did not proceed readily beyond the earlier stages, unless the passage of the contamination through the long channel of the tail-piece was facilitated by wind.]

\section{UTILIZATION OF NIAGARA FALLS.}

A SYNDICATE in the United States have acquired a considerable area of land on the American side of the Niagara River, at some distance above the great Falls. They propose to use it for mill sites, and to supply the mills with power by utilizing a small fraction of the water-power which is available on the Falls. The actual fall of level at Niagara is about 200 feet. Suppose that about 4 per cent. of the water going over the Falls is taken, and an effective fall of 140 feet, irrespective of losses in the tail race, obtained, there might be utilized 120,000 horsepower. It is proposed to take the water by a short lateral canal, to allow it to descend vertically in shafts in which turbines will be placed, and then to discharge it by a tunnel tail race passing beneath the present town of Niagara, at a point below the Falls. It is part of the plan to transmit a portion of the power to the important manufacturing town of Buffalo, eighteen miles distant.

The project involves problems of very great complexity. The hydraulic motors will be of a size not hitherto constructed, and the governing conditions are different from those commonly met with where water power is utilized on streams of variable and limited flow. Then in the distribution of the power further problems arise. Power can be distributed to great distances by Hirn's system of wire ropes, as at Schaff hausen; by water or air under pressure, as in the compressed air systems of Paris and Birmingham and the Hydraulic Power Company's system in London. In Switzerland and America progress has been made in distributing large power to great distances electrically. The choice amongst such methods of those which are most economical and most likely to suit the wants of mill-owners, requires very careful consideration.

Hence the Cataract Company have resolved to invite from certain selected engineers and engineering firms, plans for the utilization at Niagara of 120,000 horsepower, and to submit the plans for an authoritative opinion to the judgment of a Scientific International Commission. The Commission will consist of Sir William Thomson, F.R.S., as President; Prof. Mascart, Member of the Institut, and Director of the Bureau Central Météorologique, Paris ; Colonel Theodore Turrettini, who was director of the works of the Saint Gothard Tunnel, and is director of the works for the utilization of the motive power of the Rhone at Geneva; and, lastly, Dr. Coleman Sellers, formerly of the firm of Messrs. Sellers and Co., of Philadelphia, and now Professor of Engineering at the Stevens Institute, Hoboken, and at the Franklin Institute of Pennsylvania. Prof. W. C. Unwin, F.R.S., is the Secretary to the Commission.

\section{SOCIETIES AND ACADEMIES. LONDON.}

Linnean Society, June 19.-Prof. Charles Stewart, President, in the chair.-Mr. W. H. Beeby exhibited a specimen of Rumex propinquus new to Britain, and procured in Shetland. NO. IO8 I, VOL. 42$]$
- Mr. Thomas Christy exhibited and made remarks upon specimen of Callistemon rigidum.-Mr. E. M. Holmes exhibited some marine Algæ new to Britain, including Ascocyclus reptans, Halothrix iumbricalis, Harveyella nirabilis, Sorocarpus uvaformis, and Vaucheria litorea; also specimens of Rhody. menia palmata with antheridia, and Punctaria tenuissima in fructification, the last two not having been previously recorded to occur in this state in Great Britain. - The following papers were then read:- Observations on the protection of buds in the tropics, by M. C. Potter.-On the distribution of the South American Bell-birds belonging to the genus Chasmorhynchus, by J. E. Harting.-On the vertical distribution of plants in the Caucasus, by Dr. Gustav Radde.-Notes on the Forficulide, with descriptions of new genera and species, by W. F. Kirby.This meeting terminated the Session of 1889-90.

Entomological Society, July 2.-Prof. J. O. Westwood, Hon. Life-President, in the chair.-Lord Walsingham ex hibited some rare Micro-Lepidoptera collected by himself at Cannes, including Eudemis helichrysana, Conchylis rubricana, Millière ; a new Depressaria from Opoponax cheironium, which is about to be described by M. A. Constant, and Bucculatrix helichrysella; and also a-volume of drawings of larva of the genus Eupithecia, by Mr. Buckler, which formerly belonged to the late Rev. H. Harpur Crewe.-Mr. McLachlan exhibited larvæ and cocoons of Mecyna deprivalis, Walk., sent by Mr. W. W. Smith, of Ashburton, New Zealand the species feeds commonly on Genista capensis, an introduced plant.-Mr. S. Stevens, in speaking of a tour which he had lately made in Devonshire, remarked on the extreme scarcity of insects on the coast of that county as compared with the coasts of Kent and Sussex; there were very few larvæ, and the vegetation was very luxuriant and very little eaten : he thought it possible that the reason of the scarcity was the heavy rainfall of South Devon, which washed off and destroyed the young larvæ. Mr. Barrett said that his experience had been the same, and that he put it down to the violence of the winds which beat the insects from the trees. Mr. Blandford remarked that he had found Coleoptera abundant on the Braunton Burrows, near Barnstaple, but very scarce in other localities. Mr. Mason and others took part in the discussion which followed.-Prof. Westwood read a paper on a species of Aphis affecting the bread-fruit tree, which he had named Siphonophora artocurpi: at the conclusion of his paper he alluded to the use of Parisgreen as a destructive agent for insects. Mr. Blandford then made some remarks as to the use of London-purple (another arsenic compound) as an insecticide in the place of Paris-green; he stated that the compound was a waste product, and one-tenth the cost of Paris-green, and further that it was more soluble and more easily applied; he was also of opinion that arsenic compounds do not greatly affect. sucking insects, such as Aphides, the ordinary kerosene preparations being more suitable for their destruction. Several Fellows took part in the discussion that followed.

\section{EDINBURGH}

Royal Society, June I6. - The Hon. Lord M'Laren, V.P., in the chair.-A list of West Australian birds, showing their geographical distribution throughout Australia, by Mr. A. J. Campbell, Melbourne, was communicated.-Dr. Buchan discussed a difference between the diurnal barometric curves at Greenwich and at Kew.-Dr. Sang communicated a paper on the general formula for the passage of light through a spherically arranged atmosphere.-Dr. Buchan gave an account of a remarkable barometric reading at the Ben Nevis Observatory on April 8, 1890.-Prof. Crum Brown read the third part of a paper, written by himself in conjunction with Dr. James Walker, on synthesis by means of electrolysis.

July 7.- Sir William Thomson, President, in the chair.- The Victoria Jubilee Prize for $1887-90$ was presented to Prof. Tait for his work in connection with the Challenger Expedition and his other researches in physical science. The Keith Prize for r 887-89 was presented to Prof. Letts for his researches into the organic compounds of phosphorus. The Neill Prize for $1886-89$ was awarded to Mr. Robert Kidston for his researches in fossil botany.-Sir W. Thomson read a paper on the submarine cable problem, with electromagnetic induction. The solution of the problem with intermittent or alternating currents of period so long that the distribution of current over a given cross-section of the core is uniform, is already well known. Sir W. Thomson extends the solution, through all intermediate stages, to the 
case in which the period is so short that the current is confined to an exceedingly thin surface-layer of the core. He has worked out the conditions which obtain with a core and sheath of any forms. The thickness of the layer depends only, other things being equal, upon the period of alternation-the law being that given by Fourier for the penetration of the annual and diurnal heat-waves into the earth's crust. The distribution of density throughout the layer depends upon the form and relative position of the core and the sheath.-Prof. Crum Brown and Dr. James Walker, in continuation of their research on the formation of dibasic acids by electrolysis, communicated a paper on the synthesis of suberic acid and a new acid $\left(\mathrm{CH}_{2}\right)_{12}(\mathrm{COOH})_{2}$. Prof. Tait exhibited some graphic rocords of impact, obtained by the method described in a previous paper.-Dr. James Geikie read a paper by Mr. R. Kidston, on the fossil flora of the Potteries coal-field. - The Hon. Lord M'Laren read a paper on the reduction of certain algebraic equations. - Prof. Tait read an account, by Prof. A. C. Mitchell, of a preliminary experiment on the thermal conductivity of aluminium, which he makes out to be almost exactly equal to that of the best copper. $-D r$. Ralph Stockman and Mr. D. B. Dott communicated a paper on the pharmacology of morphine and its derivatives. - Dr. W. Somerville made a communication on Larix europea as a breeding-place for Hylesinus piniperda.

\section{PARIS.}

Academy of Sciences, July 7.-M. Hermite in the chair -Photographic stellar spectra obtained by MM. Henry at Paris Observatory, by Admiral Mouchez. (See Our Astronomical Column.) - On the oxidation of the sulphur of organic compounds, by MM. Berthelot, André, and Matignon. The authors give a general method for the estimation of sulphur in all organic bodies containing that element, consisting in burning the body either alone or mixed with camphor in an atmosphere of compressed oxygen in the presence of about Io c.c. of water, with subsequent precipitation of the sulphuric acid in the usual manner.- Heats of combustion of some sulphur compounds, by MM. Berthelot and Matignon.--Heats of combustion of erythrite, arabinose, xylose, raffinose, and inosite, by MM. Berthelot and Matignon.-New experiments on the silent discharge, by M. P. Schutzenberger. - The active elasticity of muscle, and the energy used in its creation in the case of static contraction, by M. A. Chauveau.-Note on the difficulty in recognizing the Cysticerca of Tenia saginata or inermis in the muscles of the calf and cow, by M. A. Laboulbène. - On the propagation of sound in cylindrical tubes, by M. V. Neyreneuf. -The theory of periodic comets, by M. O. Callandreau. The author finds that the "capture" theory of periodic comets is sufficient to explain the characteristic properties of their orbits and the objections that have been opposed to it.-On a photo graph of the ring nebula in Lyra obtained at Bordeaux Observatory, by M. G. Rayet. (See Our Astronomical Column.)Partial eclipse of the sun of June 17, by M. J. Léotard. The iimes of first and last contact are given.-Occultation of the double star $\beta$ Scorpii by the moon on June 29 , by the same author.-On the anomalous propagation of waves, by M. Gouy. -Action in the dry way of different arsenates of potassium and sodium on the sesquioxides of some metals, by M. C. Lefèvre.On a new method of preparing basic nitrate of copper and some crystallized subnitrates, by M. G. Rousseau. The basic nitrates are obtained in large crystals from the hydrates of corresponding neutral salts. - On double bromides of phosphorus and iridium, by M. G. Geisenheimer.-On some chromoiodates, by M. A. Berg. -The artificial production of boracite in the wet way, by M. A. de Gramont. - On the nitroprussides, by M. Prud'homme.-On the cause of the alteration which certain compounds of the aromatic series undergo under the influence of air and light, by M. André Bidet.Transformation of glucose into sorbite, by M. J. Meunier.On the hydrogenation of sorbine and the oxidation of sorbite, by MM. Camille Vincent and Delachanal.-Syntheses by means of cyanacetic ether : dicyanacetic ethers, by M. A. Haller. -The preparation of certain ethers by means of fermentation, by M. Georges Jacquemin.-On the physiological action of thallium salts, by Mr. J. Blake.-On the pretended circulatory system and genital organs of Neomenidæ, by M. G. Pruvot.-On the rôle of the bud-shaped pedicles of sea-urchins, by M. Henri Prouho.On the histological constitution of some Nematoids of the order Ascaris, by M. Léon Jammes.-On the comparative physiology of the sense of smell, by M. Raphael Dubois. - The basaltic eruptions of the valley of the Allier, by M. Marcellin Boule. -
On the mineralogical composition of the volcanic rocks of the islands of Martinique and Saba, by M. A. Lacroix. - On the relation between joints and some surface wrinklings near Doullens, by M. Henri Lasne.

\section{BERLIN.}

Physical Society, June 27.-Prof, von Helmholtz, President, in the chair.-Dr. Dubois spoke on magnetic closed circuits, whose theory constitutes, in addition to hysteresis, the most important advance which magnetism has made in recent times. He gave a short historical review of the more important published works on the subject, pointing out that they were at first the result rather of an endeavour to make the requisite calculations connected with dynamos for technical purposes, and had only attracted the attention of physicists in a secondary and subordinate degree. The works of Faraday, Maxwell, Sir W. Thomson, Hopkinson, Lord Rayleigh, and the experimental researches of Rowland, were briefly mentioned; Hopkinson's formulæ and Lord Rayleigh's graphic representations were then more fully treated ; and, finally, the formula for the magnetization of a closed circuit was developed.-Dr. Raps described an arrangement of Topler's mercurial air-pump, by means of which he had made it work automatically; he further described a compensated air-thermometer which he had constructed, and exhibited both instruments to the Society.

BOOKS, PAMPHLETS, and SERIALS RECEIVED.

The International Annual of Authony's Photographic Bulletin, vol. 3 r890-9r (Iliffe). - Reflections on the Motive Power of Heat: N. L. S. Car not; edited by R. H. Thurston (Macmillan and Co.).-Hypnotism : A. Moll (Blackie).-Timbers, and How to Know Theod).-Elementary Mechanic Blackie). Trimbers, and How to Know Them : Dr. R. Hartig ; translated Dr. M. C Cooke (K. Paul). - Short Logarithmic and other Tables, 4 th Dr. M. C Cooke (K. Paul). - Short Logarithmic and other Tables, $4^{\text {th }}$ Lindley (London). - Tourist Guide to the Continent: P Lindley (London). Lindley (London). - Tourist Guide to the Continent: P. Lindley (London) - Sectional Map of South Dakota (Chicago, Rand). - Pocket Map, \&c., o Michigan (Chicago, Rand).-Confidential Chats with Mothers: Mrs. Bow dick (Baillière).-British Cage Birds, Part 3: R. L. Wallace (L. Gill). Canary Book, Part $3:$ R. L. Wallace (L. Gill). - Mathematical and Physica Papers, vol. 3: Sir Wm. Thomson (Cambridge University Press). - Electric Light Fitting: J. W. Urquhart (Lockwood). - Catalogte of the Fossil
Reptilia and Amphibia in the British Museum (Natural History), Part $4:$ R. Lydekker (London). - L'Esprit de Nos Betes: E. Alix (Paris, J. B. R. Lydekker (London).-L'Esprit de Nos Bêtes: E. Alix (Paris, J. B. Baillière)-Journal of the Royal Agricultural Society, vol. I (third series), Part 2 ; General Index to ditto, second series, (Murray). - Transactions of the
Royal Society of Victoria, vol. I, Part 2 (Melbourne).-Proceedings of the Royal Society of Victoria, vol. I, Part 2 (Melbourne). - Proceedings of the
Royal Society of Edinburgh, vol. I6, pp. 385 to 846 ; vol. I7, pp. I to 128 Royal Society of Edinburgh, vol. I6, pp. 385 to 846 ; vol. I7, pp. I to I28
Edinburgh). - Transactions of the Royal Society of Edinburgh, vol. 33 Part 3 ; vol. 35 , Parts I to 4 (Edinburgh).

\section{CONTENTS.}

PAGE

The Indian Civil Service and the Indian Forest

Service Competitions . . . . . . . . 265

The Volcanoes of Hawaii. By J. W. J.

A Polyglot Medical Vocabulary. By Prof. Alex.

Macalister, F.R.S. . . . . . . . . 267

Masks from New Guinea and the Bismarck Archi-

pelago. By A. C. H. . . . . . . . . 268

Our Book Shelf :-

St. John : "Larva Collecting and Breeding" . . . , 269

Rideal : "Practical Chemistry for Medical Students" 269

Proctor : "Manual of Pharmaceutical Training" . . 270

Woodbury: "The Encyclopædia of Photography" : 270

Lock: "Dynamics for Beginners" . . . . . . . . 270

Letters to the Editor:-

"The Climates of Past Ages." - Joseph John Murphy

The American Meteor.-Rev. G. Henslow

Spontaneous Ignition and Explosions in Coal

Bunkers. By Prof. Vivian B. Lewes .....

A Winter Expedition to the Sonnblick. By Dr. J.

M. Pernter ............. 273

Bedford College . . . . . . . . . . . . 277

Notes . . . . . . . . . . . 277

Our Astronomical Column:-

Objects for the Spectroscope.-A. Fowler . . . . $28 \mathrm{r}$

Photographs and Drawings of the Sun . . . . . . 282

Observations of the Zodiacal Light . . . . . . . 282

Ring Nebula in Lyra

Photographs of Stellar Spectra ... . . . 282

On the Superficial Viscosity of Water. (Illustrated.)

By Lord Rayleigh, Sec.R.S. . . . . . . . . . 282

Utilization of Niagara Falls . . . . . . . . 287

Societies and Academies . . . . . . . . . . 287

Books, Pamphlets, and Serials Received . . . 288

NO. IO8I, VOL. 42 ] 